\title{
The Origin of Copernicus's Heliocentrism Reconsidered
}

The essay re-examines the detailed arguments by Ludwik Antoni Birkenmajer (1855-1929) and Curtis Wilson (1921-2012) about how Copernicus's rejection of Ptolemy's solution to the problem of the non-uniform motions of the planets and the Moon led him to his first version of the heliocentric theory. The essay then acknowledges the speculative character of their reconstructions, the problem of anachronism in both accounts, and the mistakes that Copernicus himself made. By following their basic insights, however, readers can understand how the inconsistency in Ptolemy's preservation of the axiom of uniform motion motivated Copernicus - first, to seek an alternative solution, and, second, to question eccentrics, which, in turn, led him to investigate epicycles. The concluding section complements their accounts, leading to an original interpretation of Copernicus's reliance on medieval Polish developments in dialectical reasoning and on a comment in one of the books (now at Uppsala) that he annotated to develop his new vision and to construct the postulates near the beginning of Commentariolus (ca. 1510).

Keywords: Albert of Brudzewo, Ludwik Birkenmajer, Commentariolus, Nicholas Copernicus, cosmography, dialectical topics, eccentrics and epicycles, equants, postulates, uniform motion, Curtis Wilson

Słowa kluczowe: Albert z Brudzewa, Ludwik Birkenmajer, Commentariolus, Mikołaj Kopernik, kosmografia, topika dialektyczna, deferenty i epicykle, ekwanty, postulaty, ruch jednostajny, Curtis Wilson

\section{Introduction}

In a recent article on Ludwik Antoni Birkenmajer and Curtis Wilson on the origin of Copernicus's heliocentrism, I engaged in a dialectical exercise by examining the standard accounts, and raised questions and doubts that led to a reconsideration of Copernicus's comments about his objections to Ptolemy's model for saving uniform motion. ${ }^{1}$ In my 
monograph on the relation of Copernicus to the Aristotelian tradition in Kraków, I emphasized the developments in dialectical exercises using topics or commonplaces, and how instructors might have influenced Copernicus to develop the petitions or postulates at the beginning of Commentariolus and the argumentative strategies that Copernicus employed particularly in Book I of De revolutionibus. ${ }^{2}$

Without repeating all the details that made the previous explanations of the origin of Copernicus's heliocentrism unsatisfactory, I shall add something about the hesitation to return to Copernicus's comments about non-uniform motions and the equant model. The absoluteness with which reconstructions based on Copernicus's criticism of the equant were rejected certainly discouraged pursuing that path, and the fact that there were geocentric versions without equants along with Copernicus's own 'hidden' equant supported the rejection of that explanation. ${ }^{3}$

\section{Birkenmajer on the Origin of Copernicus's Heliocentrism}

Still, Copernicus's words and comments were troublesome. While translating Ludwik Birkenmajer's Chapter 7 of his massive materials towards a biography of Copernicus, I encountered a reconstruction that benefited from then recent discoveries and a fresh approach to Copernicus's background in Kraków. ${ }^{4}$ Birkenmajer based his reconstruction in part on his reading and edition of Albert of Brudzewo's Commentariolum on Peurbach's New Theorics of the Planets and on his critique of earlier authors about the relation between Copernicus's Commentariolus and De revolutionibus. ${ }^{5}$ Out of these materials and critique, Birkenmajer constructed an explanation that began with Copernicus's objections to the equant, presented as a major first step that involved the rejection of geocentrism accompanied by a separate, though closely related, formulation of a heliocentric system. And the latter stage itself also involved two stages.

2 Idem, Copernicus and the Aristotelian Tradition: Education, Reading, and Philosophy in Copernicus's Path to Heliocentrism, Leiden and Boston 2010, esp. chapter 3, p. 243-256, and chapter 8.

3 It is now well-known that Michael Mästlin was the first to notice Copernicus's oversight, and it has been repeated by several scholars as principal evidence against Copernicus's own objections. Even allowing for this correction, however, we still must reckon with Copernicus's focus on the first anomaly as his starting point, and on his objections to Ptolemy's solution for the first anomaly. See Mästlin's letter to Kepler dated 9 March 1597 in J. Kepler, Gesammelte Werke, ed. by W. van Dyck, M. Casper, Munich, 1937-, vol. 13, no 63: 108-112, at p. 110, lines 98-102 and 107-109.

4 L.A. Birkenmajer, Mikołaj Kopernik, Część pierwsza, Studya nad pracami Kopernika oraz materyały biograficzne, Cracow 1900. See also: idem, Stromata Copernicana: Studja, poszukiwania i materjały biograficzne, Cracow 1924, especially p. 83-103.

5 Albertus de Brudzewo, Commentariolum super Theoricas novas planetarum Georgii Purbachii per Mag. Albertum de Brudzewo diligenter corrogatum A. D. MCCCCLXXXII, ed. by L.A. Birkenmajer, Cracow 1900. In Stromata, p. 90-91, Birkenmajer expressed himself clearly on the relation he saw between de Brudzewo and Copernicus: "Za wspólną obydwom naszym autorom myśl, wzgl. filjację ich wyobrażeń uważam także te miejsca ich pism, w których, z przyczyn logicznych, zwracają się oni przeciwko pewnym kołom w Ptolemeuszowym mechanizmie, t. zw. ekwantom. Wiadomo, że ekwant księżyca był głównym zdrajcą rozumowej sprzeczności, tającej się w starej teorji satelity ziemskiego, i że wykrycie przez Kopernika owej sprzeczności było stanowczym ciosem zadanym starej doktrynie geocentrycznej." ["That the authors [Brudzewo and Copernicus] had the same ideas or related concepts in common, I see also in passages of their texts where they react on logical grounds against certain circles in the Ptolemaic mechanism, the so-called equant. We know that the lunar equant betrayed the principal rational contradiction contained in the old theory of Earth's satellite, and that Copernicus's discovery of the contradiction was the decisive blow by means of which he replaced the old geocentric doctrine."] 
Beginning with Commentariolus, Birkenmajer believed that Copernicus rejected not just the equant but also the eccentric, which he saw as related, and which also contributed to doubts about Ptolemy's epicycles. This was all part of a critique of geocentrism, the chief features of which involved questions that geocentrism could not answer, or problems that geocentrism did not possess the resources to resolve.

Among the doubts about Ptolemy's epicycles was the large size of all the epicycles, some of which were really huge. With Copernicus's bi-epicyclic radii compensating for the elimination of the equant and eccentric (the $3: 1$ ratio), he could compensate for the huge Ptolemaic epicycles by means of Earth's annual motion around the Sun. Birkenmajer commented: 6

Czytelnik Revolutionum napróżno szukałby uzasadnienia podziału 1:3 i jego genezy w anteriorach tekstu. Występuje on naraz, bez żadnego motywowania lub powołania się na jaką analogię. Dlaczegóż to, możnaby zapytywać, stosunku tego nie obrano równym n. p. 1:2, lub 2:5, 3:8 i t. p.; co więcej, dlaczego zgoła dla różnych planet nie przyjęto różnych takich stosunków? Ptolemeusz dzieli wprawdzie mimośród excentryka w stosunku 1:2, ale z tego podziału korzysta on tylko przy wprowadzaniu ekwantów, nie zaś przy ustalaniu rozmiarów epicyclów: w Almageście stosunki promieni tych kół do przynależnych im deferensów u różnych planet mają wartości całkiem odmienne i żadnemu wyrażniejszemu prawu nie ulegające.

In a footnote he added the following explanation: ${ }^{7}$

Ptolemeusz [...] wyrażając promień excentryka będącego deferensem (t. j. ekwanta, obydwóch promienie są bowiem jednakie) liczbą 60, znajduje dla mimośrodów i promieni epicykla następujące wartości: Mars 12 i $39 \frac{30}{60}$ (!); Jowisz $5 \frac{30}{60}$ i $11 \frac{30}{60}$; Saturn $6 \frac{50}{60}$ i $6 \frac{30}{60}$. Stąd wypadają rzeczone stosunki: dla Marsa $3 \frac{7}{24}$, dla Jowisza $1 \frac{4}{35}$. Kopernik ma ten stosunek równym $\frac{1}{3}$ dla wszystkich; ogromne epicykle starej teoryi odpadły z chwilą, gdy po raz pierwszy do konstrukcyi wprowadził ruch ziemi.

By 1523, however, with the variability of the planetary apsides confirmed, Copernicus replaced the bi-epicyclic arrangement with the trisection of the eccentric in Revolutions.

6 L.A. Birkenmajer, Mikołaj Kopernik, p. 187-188: "The reader of Revolutions would look in vain for any justification of the ratio $1: 3$ in the earlier work [Commentariolus]. This ratio appears in Revolutions all of a sudden without any reference or comparison. We can justly ask, what made the author select exactly this ratio and not any other instead, for example, $1: 2,2: 5,3: 8$, etc.? Moreover, what made him choose one ratio for different planets? Although Ptolemy divided the eccentricity of the eccentric deferent into the ratio $1: 2$, he resorted to such a division only while introducing the equants, not to establish the dimensions of the epicycles. In Almagest, the ratios of the semi-diameters of the epicycles to their respective deferents have quite different values for different planets, and are not subject to any more definite rules."

7 Ibid, p. 188, note 1: "By setting the radius of the eccentric deferent equal to 60 (i. e. with the equant, both radii are in fact equal), Ptolemy [...] found the following values for the eccentrics and epicycle radii: Mars 12 and $39 \frac{30}{60}(!)$; Jupiter $5 \frac{20}{60}$ and $11 \frac{20}{60}$; Saturn $6 \frac{50}{60}$ and $6 \frac{30}{60}$. Thus, we obtain the following ratios: $3 \frac{7}{24}$ for Mars, and $1 \frac{4}{25}$ for Jupiter. The ratio in Copernicus is $\frac{1}{2}$ for all the superior planets. He replaced the huge epicycles in the old theory with the radius of Earth's orbit as soon as the motion of Earth became one of the factors of the whole structure." By including the equant, Birkenmajer did not bisect the eccentricities in the numbers above but used the total eccentricity. The resulting ratio for Jupiter should be $2 \frac{1}{11}$. 
When Birkenmajer asserted that the elimination of the huge epicycles was the consequence only of the rejection of the equant, what he meant is that the rejection of the equant provoked doubts about the rest of Ptolemy's system, beginning with eccentrics and extending to the huge epicycles. Birkenmajer recognized, of course, that Earth's annual motion compensated for Ptolemy's large epicycles, as he remarks in the footnote above.

Birkenmajer was not completely clear on the introduction of Earth's annual motion around the Sun, but I take his argument to be that once Copernicus had reached the conclusion that geocentrism was fatally flawed, it necessitated the introduction of a system with another center, and since the motions of all of the planets had been linked to the Sun, and because the variations in distance of Mars and Venus from Earth required another explanation, then it followed, Birkenmajer thought, that Copernicus proposed the Sun as center with Earth in motion around it. To summarize the argument, then, we may cite the following texts from Birkenmajer: ${ }^{8}$

Równość owych stosunków u różnych planet była już tylko następstwem przebiegu wielkiego odkrycia: odrzucenia nasamprzód nielogicznych ekwantów, w ślad za czem i rozpaczliwie wielkich, nieprawdopodobnych epicyklów, a zastąpienie wszystkich jednym jedynym ruchem dorocznym ziemi około słońca, wywołującym u planet te same ruchy pozorne, które przez wieki poczytywano za rzeczywiste.

Birkenmajer believed that Copernicus saw in Ptolemy's equant a logical contradiction that was fatal not only for his solution to the problem of uniform motion but for geocentrism altogether, for after restoring the eccentrics, he saw a way to eliminate the huge epicycles from the system: ${ }^{9}$

Odrzucenie niemożliwych logicznie ekwantów u planet zachwiało całą starą budowlą astronomiczną; usunięcie zaś ogromnych jej epicyklów - będące już tylko następstwem tamtego - zwaliło ją doszczętnie. Ta czynność krytyczna w umyśle wielkiego męża, zakończona nareszcie aktem właściwej twórczości, występuje dzisiaj przed nami, dzięki wydobyciu na jaw tylu zapisek, z wyrazistością dostateczną, aby módz śledzić jej przebieg przynajmniej we fazach główniejszych.

He then put it all together in a long paragraph: ${ }^{10}$

8 Ibid., p. 188: "The equality of all planetary ratios was a consequence of some findings that led to the great discovery. First, Copernicus rejected the illogical equants, which also ruled out the impossibly huge epicycles. All of this he replaced with the yearly motion of Earth around the Sun, which accounted for the same apparent motions of the planets as those that for several centuries had been regarded as real."

9 Ibid., p.190: "The rejection of the logically impossible planetary equants shook the old astronomical edifice in its entirety. The elimination of the huge epicycles, a consequence only of his rejection of the equant, destroyed the old astronomy completely. The great man's mind crowned the critique with the great work itself, which, thanks to his many annotations, appears today with sufficient clarity for us to follow its essential stages."

10 Ibid., p. 190-191: "The necessity for the precise distinction between two stages in his intellectual work is evident. No new idea can take root without uprooting the old doctrine, a process that cannot occur all at once [...] [sic] Before the new idea arose in his mind, then, he had to tear down the cornerstone (equants) of the old science, and thereby weaken the entire structure in such a way as to fill him with doubts about the rest of it, especially with respect to eccentrics, to which category, after all, the rejected equant belonged. All our investigations prove that this was the path that our astronomer's thinking followed and that the sketch of its origin is more than just a guess. The Com- 
Konieczność pilnego wyróżniania obydwóch tych stadyów pracy duchowej Kopernika jest oczywistą: wszak nawet rozmyślania nad jakąś nowością nie miałyby racyi bytu, gdyby wprzód starej doktryny nie odrzucono, co przecież naraz stać się nie mogło [...] [sic] Wpierw jednak jeszcze, zanim ta nowość w myśli jego powstała, samo wyjęcie kamienia węgielnego ze starej budowy (ekwanty) musiało całość nadwątlić, napełnić go niewiarą w prawdziwość reszty urządzenia, w pierwszym zatem rzędzie samych mimośrodków, do których należał przecie i odrzucony ekwant. Że taki to proces odbywała myśl naszego astronoma i że ten szkic jej pochodu jest czemś więcej aniżeli tylko domysłem, zaświadcza to całość naszych dochodzeń. Znamienne w tej mierze świadectwo przechował nam także Commentariolus. Widzimy tam wszystkie planety (z jedynym wyjątkiem ziemi) zupełnie bez excentryków, w ich miejscu zaś - identyczne co do skuteczności z nimi - koła homocentryczne, każde z pewną ilością małych epicyklów, a wreszcie ową nowość: ruch ziemi dokoła słońca, wprowadzony zamiast gromady ogromnych epicyklów Ptolemeusza. Tak tedy wsunięcie tego nowego kamienia węgielnego w miejsce wyjętogo, odebrało całkowicie racyę bytu wszystkim ekwantom i zamieniło je najpierw w zwykłe mimośrodki. Stało się to przez wspólne dla wszystkich przesunięcie w tym samym dla wszystkich (Ptolemeuszowym) stosunku 1:2 środka deferensa aż do nakrycia się ze środkiem mimośrodka i również wspólne dla wszystkich przemieszczenie obserwującego oka. Obie te zmiany żądały, ze względów już czysto geometrycznych, rozdzielenia wszystkich mimośrodów planetarnych w tym samym stałym stosunku. Niedowierzanie mimośrodkom wogóle - do ich kategoryi należał bowiem fatalny ów ekwant - posunęło tego dziwnego budowniczego aż do skrajności: usunięcia ich prawie doszczętnego, przyczem nagrodzono homocentrykom stracony mimośród małym epicyklem, nadając mu rozmiary stosowne do poniesionej na mimośrodzie straty. To nam wyjaśnia zupełnie, skąd poszło, że stosunki promieni epicyklów ma Commentariolus dla wszystkich planet jednakie ( $\left.\frac{1}{3}\right)$,

mentariolus contains important testimony for it. All the planets (with exception of Earth) are without eccentrics, all replaced with concentric circles, identical as to their function, each with a definite number of small epicycles, and the innovation, the Earth's motion around the Sun in place of the numerous huge epicycles in Ptolemy's system. The replacement of the old cornerstone with a new one deprived all the equants of their function and turned them into nothing but eccentrics, because by shifting the deferent's center until it became identical with the center of the eccentric and the observer's eye, it became common for all the planets. For purely geometrical reasons both changes require the separation of all the planetary eccentrics according to the same ratio. Because the fatal equant belonged to this category, lack of confidence in the eccentrics as such led this curious architect to the extreme of their nearly absolute elimination and replacement by the small epicycle with a dimension proportional to the elimination of the eccentric. This explains thoroughly how it happened that Commentariolus has the same ratio of $1: 3$ for the semidiameter of all the planetary epicycles, and this corresponds to the trisection of the eccentric in Revolutions. The same can be observed in the Uppsala Notes. Only the significantly later discovery of the mobility of the planetary apsides made Copernicus, as he himself says, replace the larger (that is, the first) epicycle again with the eccentric of the main circle, leaving the smaller epicycle, which in no way violated the foundations of the heliocentric system. Although Revolutions does not mention when this change took place, one of the annotations in the Uppsala Notes announces that it took place in 1523 and in the following years."

Regarding the discovery about the apsides, Birkenmajer explained in footnote 3, "Przypominam, że wykrycie ruchomości apogeum pozornej drogi słońca, t. j. absydy rzeczywistej drogi ziemi nastąpiło w r. 1515 (zob. Rozdział I, III i VII). Pozostałe planety musiały długo jeszcze czekać, zanim wykrył Kopernik także i dla nich ten sam fakt przyrody." ["Recall that he had already discovered the mobility of the apogee of the apparent solar path, that is, the apsides of, in fact, the terrestrial path in 1515 (see chapters 1, 3, and 7). It must have taken Copernicus a long time to discover the same phenomenon for the remaining planets."] 
odpowiadającie owej trysekcyi mimośrodu, jaką w głównem Dziele przyjęto: zobaczymy, że i w zapisce upsalskiej to samo występuje. Dopiero znacznie późniejsze wykrycie ruchomości absyd planetarnych skłoniło Kopernika - sam to powiada aby większy (t.j. pierwszy) epicykl zastąpić napowrót mimośrodem koła głównego, pozostawiając mniejszy, czem oczywista nie naruszono w niczem samych podwalin heliocentrycznego układu. Wprawdzie Revolutiones nie wspominają o czasie kiedy to zaszło, ale jedna z pośród przytoczonych już zapisek w Raptularzyku oznajmia, że stało się to w r. 1523 i kilku następnych [brackets added - A.G.].

\section{Curtis Wilson on the Origin of Copernicus's Heliocentrism}

At this point in my reconstruction of Birkenmajer's argument, I was reminded by Robert Westman of Curtis Wilson's return to the problem of observed non-uniform motions as the starting-point for Copernicus's formulation of heliocentrism. ${ }^{11}$

For Wilson, the central question was about the connection between the axiomatic adoption of uniform, circular motion and Earth's annual motion. To put it a little more bluntly than Wilson did, what did Earth's annual motion have to do with saving the uniform, circular motions of the planets? That was the question that Wilson tried to answer.

First, in order to eliminate the equant, Copernicus introduced new epicycles (the biepicyclic arrangement of Commentariolus). Wilson noticed, and he presumed that Copernicus did as well, that Ptolemy's models for the superior planets mounted on top of the bi-epicyclic arrangement to account for the Sun's annual motion would require the epicycles to follow the Sun's mean motion, meaning that the geostatic version would replace uniform motions with the Sun's mean motion. In other words, the motion of a planet on the epicycle amounted to an annual epicycle, and because the motion must be uniform around its proper center, Copernicus considered giving the annual epicycle a place and center of its own. Copernicus would then have seen the possibility of transforming the annual epicycle for the superior planets into the annual motion of the Sun or Earth. ${ }^{12}$

So, according to Wilson, Ptolemy's violation of the principle of uniform motion did give Copernicus occasion to consider Earth's motion. The remainder of Wilson's account is taken up with some consideration (not a full explanation) of the reasons for preferring the motion of Earth over the motion of the Sun, and the problem of trying to fit the models for Venus and Mercury into the account. Because Copernicus had succeeded in reducing the sizes of the epicycles for the superior planets, it seemed to me that Wilson, focused as he was on transformation of models, overlooked the possibility that Copernicus would have seized on the result (the reduction in the size of the epicycles for the superior planets) and apply it to Venus and Mercury, at least with respect to the elimination of the large epicycles.

11 C. Wilson, Rheticus, Ravetz, and the 'Necessity' of Copernicus' Innovation, [in:] The Copernican Achievement, ed. by R.S. Westman, Berkeley, Los Angeles, London 1975, p. 17-39.

12 See C. Wilson, op. cit., p. 28-36, and his Figures 2 and 5. 
In reconsidering my reliance on Birkenmajer and Wilson, I have since put forward two further suggestions. Acknowledging the speculation in both accounts and the mistakes that Copernicus made, I have tried to simplify the argument or explanation with the first suggestion to follow.

Commentariolus and De revolutionibus I, 4 are in agreement about (1) the principle of uniform motion, (2) the failure of geostatic and geocentric efforts to maintain uniform motions around proper centers, and (3) the result that everything could be made to move uniformly and also account for variations in the distances of planets from Earth. From a model with Earth in motion Copernicus proposed to account for the variations in distance and the irregularities while everything moved uniformly.

What were the fundamental steps? If Earth is not the center of the observed motions, and if the planetary motions are related to the Sun, then the planetary spheres may encircle the Sun approximately in the middle of their motions. With the Earth-Sun distance very small in comparison with the Sun's distance from the stars, we could not perceive Earth's motion relative to the Sun or the stars. The Capellan arrangement may have played a suggestive role, but because a geostatic system has no proper center, and since the appearances are equivalent, he proposed Earth's motions and proceeded to work out the details. As he made this proposal in Commentariolus, he distinguished it from so-called Pythagorean assertions of Earth's motions because theirs was unwarranted, whereas his followed from the failure of geostatic/geocentric accounts and from the equivalence of appearances. ${ }^{13}$

In De revolutionibus I, 4, Copernicus posed the question whether the observed nonuniformities (particularly, variations in distance and non-uniform motions) occur in the heavens or are related to Earth. He implied that the motion of Earth is the cause of observed non-uniformities. With Earth in motion, the distances of the planets will vary, and their motions will appear unequal in equal times.

By constructing a system with Earth moving around a static Sun, he claimed that he could account for the apparent non-uniformities while having the planets move uniformly in circles around their proper centers. The details also had consequences for eccentrics and the size of epicycles, and the determination of a unique order for the planetary spheres.

The challenge was to construct a system with all planets (except Earth) in motion around either a centered Sun, eccentric to Earth, (initially in Commentariolus) or all planets including Earth around a static Sun near the center (Revolutions) in such a way as to preserve planets' uniform, circular motions around their proper centers.

13 See the critical edition: M. Kopernik, De hypothesibus motuum caelestium a se constitutis commentariolus, ed. by J. Dobrzycki, [in:] M. Kopernik, Pisma pomniejsze. Dzieła wszystkie, vol. 3, Warsaw 2007, p. 11: "Proinde ne quis temere mobilitatem Telluris asseuerasse cum Pythagoricis nos arbitretur, magnum quoque et his argumentum accipiet in circulorum declaratione." In Edward Rosen's translation: "Accordingly, lest anybody suppose that, with the Pythagoreans, I have asserted the earth's motion gratuitously, he will find strong evidence here too in my exposition of the circles." See N. Copernicus, Commentariolus, tr. by E. Rosen, [in:] N. Copernicus, Complete Works. Vol. 3: Nicholas Copernicus Minor Works, Warsaw 1985, p. 82. Noel Swerdlow, The Derivation and First Draft of Copernicus's Planetary Theory, "Proceedings of the American Philosophical Society" vol. 117, p. 439, translates "temere" as "for no good reason." 
I now turn to the second suggestion, a reconsideration that re-interprets Birkenmajer's analysis. We all know that Copernicus did not succeed in effecting a revolution in astronomy. This achievement is properly and correctly assigned to Kepler. Copernicus, however, did initiate a revolution in cosmology, but that means that his contribution was to develop and formulate concepts of modern cosmography within the conceptual framework of pre-modern cosmography, which either did not possess those concepts or rejected some of them as physically impossible. To account, then, for Copernicus's conceptual change, Birkenmajer emphasized his recognition of problems with and inconsistencies in the existing conceptual systems. That was Birkenmajer's contribution, although Birkenmajer himself tended to assimilate Kepler's achievement to Copernicus's. If we remove the anachronistic features in Birkenmajer's account, we are left with Copernicus's critique of Ptolemaic astronomy, which Copernicus himself stressed and which Rheticus confirmed. ${ }^{14}$

Copernicus's retention of the axiom of uniform, circular motion (a pre-modern concept) and his critique of what he perceived as an inconsistency in Ptolemy's preservation of that axiom motivated him, first, to seek an alternative solution, and, second, to question eccentrics. In the process of evaluating eccentrics, he also began, third, to investigate epicycles, and in this stage Copernicus became suspicious of Ptolemy's huge epicycles as an explanation of variations in distance. In his first version, as we know, he eliminated the eccentrics, proposing concentric models with a thoroughly bi-epicyclic arrangement (except for Earth), - perhaps suggested by the solution of the lunar prosneusis problem, which with Earth in motion annually also entailed a reduction in the size of epicycles. ${ }^{15}$ Later, with eccentrics restored, he could reduce the epicycles even further in a heliostatic, approximately heliocentric, system. From an ancient cosmological concept Copernicus developed and formulated a new cosmological concept.

The dialectical exercise summarized above is not a rational reconstruction but reflects Copernicus's own training in dialectic and dialectical questioning. These are habits of mind that he most likely developed at the University of Cracow and possibly reinforced through his legal training at Bologna. ${ }^{16}$ The crucial technique was the application of dialectical topics, especially the whole/part topos, from an integral whole. This dialectical topic served Copernicus in his defense of the heliocentric hypothesis, and also in developing his cosmographical vision. ${ }^{17}$ Returning to the process of dialectical questioning that reflects Copernicus's own argumentative strategies and relying on a significant Copernican an-

14 Rheticus explains the reasons why ancient hypotheses must be abandoned in a section of Narratio prima (sometimes numbered 8), in which he seems also to argue that the connection of planetary models with the motion of the Sun and the entire harmony of the celestial motions as controlled by the Sun motivated Copernicus to put the planets with Earth in motion around the Sun. See now the facsimile version in Georg Joachim Rheticus, Narratio Prima or First Account of the Books On the Revolutions by Nicolaus Copernicus, with an introduction by Jarosław Włodarczyk, based on the copy of the first edition, Gdańsk 1540 (Truszczyny, Warsaw 2015), f. Ciiir-Civv.

15 On the lunar prosneusis problem see the appendix on Ptolemy's lunar model under Ludwik Antoni Birkenmajer Citations on my website: andregoddu.strikingly.com [accessed 20.11.2018].

16 On the teaching of logic at Cracow, see A. Goddu, Copernicus, chapter 3. See also the magisterial study of $15^{\text {th }}$-century Cracow University by Paul W. Knoll, "A Pearl of Powerful Learning" The University of Cracow in the Fifteenth Century (Education and Society in the Middle Ages and Renaissance, 52), Leiden 2016, chapters 6-7, and p. 674-679, especially p. 678. On Bologna, see A. Goddu, Copernicus, p. 181-184.

17 See A. Goddu, Copernicus's Mereological Vision of the Universe, "Early Science and Medicine" vol. 14, 2009, p. 316-339. 
notation in the copy of Marsilio Ficino's translation of Plato's Parmenides, ${ }^{18}$ I reframe the questions (characterized by Copernicus as "petitiones") that he posed near the beginning

of Commentariolus in the following way:

1. Do the celestial spheres have one center or many centers? If many (Postulate 1), then

2. Earth cannot be the center of the universe but only of gravity and of the lunar sphere (Postulate 2).

3. Why are the models for all planetary spheres related to the position of the Sun? If their motions are relative to the Sun, then let us suppose that the planetary spheres encircle the Sun approximately in the middle of their motions (Postulate 3).

4. If Earth's distance from the Sun is very small in comparison with the Sun's distance from the stars, then could we perceive Earth's motion relative to the Sun or the stars? (Postulate 4).

5. If not, then which motions are merely apparent and possibly due to Earth's motions, and which are the proper motions of the spheres? Do the stars and the entire universe rotate once a day around Earth east to west, or does Earth rotate on its axis west to east? (Postulate 5).

6. Does the Sun move around Earth once a year, or does Earth with its sphere and any other planet move around the Sun once a year, thus moving with more than one motion? (Postulate 6).

7. Do the planets really move backwards and then forwards, or does Earth's annual motion account for these and other apparent irregularities? (Postulate 7).

The conclusions that natural philosophers reach about the immobility of Earth rest on appearances here on Earth, but Earth's immobility is itself an appearance (Copernicus's version of the principle of the relativity of motion). When confronted with two appearances that contradict one another, by what principles, standard, or criterion shall we remove the contradiction? Shall we begin with a stationary Earth that inevitably generates an uncertain and arbitrary arrangement of the spheres of Venus and Mercury, or begin with a vision of the whole cosmos that settles and determines the positions of the planets uniquely? Copernicus concluded that geocentrism led to the violation of uniform motion relative to the deferent center and epicycle center, did not lead to consensus on the ordering of the planets, and accounted for irregularities in motion and distances by resorting to large epicycles and motions of spheres that were uniform but not relative to the centers of their spheres. By means of his seven postulates, Copernicus claimed that he could account for every apparent irregularity while keeping everything moving uniformly, and that the hypotheses about Earth's motions were part of the solution.

As is clear later, however, from his own words in De revolutionibus III, 20 and V, 4, Copernicus rather solved the problem of uniform motion approximately and, in his own view, more adequately than his geocentric predecessors had. We can now see that medieval developments in dialectical argumentation influenced him to depart from ancient and medieval conceptions in cosmography. Above all, by means of the postulates and the topos, from an integral whole, he could determine the order of the spheres between

18 See idem, Copernicus's Annotations-Revisions of Czartoryski's 'Copernicana', "Scriptorium" vol. 58, 2004, esp. p. 210-215 and Plate 42. See also idem, Copernicus, p. 225-228 and 251-256. 
the fixed stars at the periphery and the stationary Sun near the center uniquely according to sidereal periods with the Moon going around Earth between the spheres of Mars and Venus. He could claim, as Rheticus did in his account, that he had established a perpetual and consistent connection and harmony of celestial phenomena where the order and motions of heavenly spheres agree in an absolute system. ${ }^{19}$

For these reasons, it seems to me that Birkenmajer was right to take Copernicus at his word about Ptolemy's solution to the problems of uniform motion, and that the hypotheses about Earth's motions were part of the solution. He was also right to believe that Copernicus would have regarded equivalent geocentric versions as incapable of generating a uniquely ordered system of heavenly spheres.

\section{Acknowledgments}

I am very grateful to Jarosław Włodarczyk of the Polish Academy of Sciences and to Robert Szaj of the Nicholas Copernicus Foundation for their generous hospitality and invitations to give lectures on Birkenmajer. This summary is an expanded version of the lecture delivered in Warsaw.

\section{Bibliography}

\section{Critical literature}

Birkenmajer L.A., Mikołaj Kopernik, Część pierwsza, Studya nad pracami Kopernika oraz materyały biograficzne, Cracow 1900.

Birkenmajer L.A., Stromata Copernicana: Studja, poszukiwania i materjały biograficzne, Cracow 1924.

Goddu A., Copernicus and the Aristotelian Tradition: Education, Reading, and Philosophy in Copernicus's Path to Heliocentrism, Leiden and Boston 2010.

Goddu A., Copernicus's Annotations-Revisions of Czartoryski's 'Copernicana', "Scriptorium" vol. 58, 2004, p. 202-226.

Goddu A., Copernicus's Mereological Vision of the Universe, "Early Science and Medicine" vol. 14, 2009, p. 316-339.

Goddu A., Ludwik Antoni Birkenmajer and Curtis Wilson on the Origin of Nicholas Copernicus's Heliocentrism, "Isis" vol. 107, 2016, p. 225-253.

andregoddu.strikingly.com [accessed 20.11.2018].

Knoll P.W., "A Pearl of Powerful Learning" The University of Cracow in the Fifteenth Century (Education and Society in the Middle Ages and Renaissance, 52), Leiden 2016.

Swerdlow N., The Derivation and First Draft of Copernicus's Planetary Theory, "Proceedings of the American Philosophical Society" 117, p. 423-512.

Wilson C., Rheticus, Ravetz, and the 'Necessity' of Copernicus' Innovation, [in:] The Copernican Achievement, ed. by R.S. Westman, Berkeley, Los Angeles, London 1975, p. 17-39. 


\section{Sources}

Brudzewo A. de, Commentariolum super Theoricas novas planetarum Georgii Purbachii per Mag. Albertum de Brudzewo diligenter corrogatum A. D. MCCCCLXXXII, ed. by L.A. Birkenmajer, Cracow 1900.

Copernicus N., Commentariolus, tr. by E. Rosen, [in:] N. Copernicus, Complete Works. Vol. 3: Nicholas Copernicus Minor Works, Warsaw 1985.

Kepler J., Gesammelte Werke, ed. by W. van Dyck, M. Casper, Munich, 1937-, vol. 13, no 63.

Kopernik M, De hypothesibus motuum caelestium a se constitutis commentariolus, ed. by J. Dobrzycki, [in:] Pisma pomniejsze. Dzieła wszystkie, vol. 3, Warsaw 2007.

Retyk J.J., Narratio Prima. Relacja pierwsza z ksiąg O obrotach Mikołaja Kopernika, transl. by I. Lewandowski, introduction by J. Włodarczyk, Truszczyny, Warsaw 2015.

Rheticus G.J., Narratio Prima, Gdańsk 1540.

ANDRÉ GODDU is emeritus professor in the Department of Astronomy and Physics, Stonehill College, Easton, Massachusetts, USA. He is preparing a modern translation into English of Ludwik Birkenmajer's massive materials towards a biography of Copernicus published in Cracow in 1900. E-mail: andre.goddu@gmail.com 